\title{
THE IMPROVEMENT OF MATHEMATICS LEARNING ACHIEVEMENT BY IMPROVING TEACHER PERFORMANCE CAPABILITIES THROUGH GUIDANCE AND SUPERVISION BY PRINCIPALS
}

\author{
Rohaimi \\ SD Negeri 137 Pekanbaru, Pekanbaru, Indonesia \\ rohaimispd@gmail.com
}

\begin{abstract}
Mathematics is a study that has an abstract object and is built through a process of deductive reasoning which the truth of a concept is obtained as a logical consequence of the truth previously accepted so that the relationship between concepts in mathematics is very strong and clear. In the implementation of the teaching and learning process of Mathematics in elementary schools, the various methods are used and adapted to the material presented by educators or teachers. It is intended if problems occur and difficulties in learning Mathematics will be easily solved. In this case the writer used the Guidance and Supervision by Principal's method. This school action research consisted of two cycles, namely cycle I and cycle 2. Where in each cycle consisted of action planning, action implementation, observation and reflection. This research was conducted in sixth grade students of SDN 137 Pekanbaru. The analysis technique was carried out qualitatively and quantitatively. This research aimed to improve student achievement in learning mathematics through guidance and supervision by principal. The results showed that with the supervision by principals had increased by 30\%, the student learning outcomes averaged 62.66 to 85.33 by increasing student learning achievement. Thus, it can be concluded that with the guidance and supervision by principals can improve student learning achievement. Therefore, it is hoped that it will always improve the ability of its performance in learning so that the quality of education in schools increases.
\end{abstract}

Keywords: mathematics learning achievement, teacher performance capabilities and guidance and supervision

\section{PENINGKATAN PRESTASI BELAJAR MATEMATIKA DENGAN MENINGKATKAN KEMAMPUAN KINERJA GURU MELALUI BIMBINGAN DAN SUPERVISI KEPALA SEKOLAH}

\begin{abstract}
ABSTRAK
Matematika merupakan suatu bahan kajian yang memiliki objek abstrak dan dibangun melelui proses penalaran deduktif, kebenaran suatu konsep diperoleh sebagai suatu akibat logis dari kebenaran sebelumnya sudah diterima, sehingga keterkaitan antar konsep dalam matematika bersifat sangat kuat dan jelas. Dalam pelaksanaan proses belajar mengajar Matematika di Sekolah Dasar tentu saja digunakan berbagai metode yang disesuaikan dengan materi yang di sajikan pendidik atau guru. Hal ini dimaksudkan apabila terjadi permasalahan dan kesulitan dalam belajar Matematika akan mudah diselesaikan. Dalam hal ini penulis menggunakan metode Bimbingan dan Supervisi Kepala Sekolah. Dalam penelitian tindakan sekolah ini terdiri dari dua siklus yaitu siklus I dan siklus 2. Dimana dalam setiap siklusnya terdiri atas perencanaan tindakan, pelaksanaan tindakan, observasi dan refleksi.Penelitian ini dilaksanakan pada siswa kelas enam Sekolah Dasar Negeri 137 Pekanbaru.Tehnik analisis dilakukan secara kualitatif dan kuantitatif, Penelitian ini bertujuan guna, meningkatkan prestasi belajar siswa dalam pembelajaran Matematika melalui bimbingan dan Supervisi Kepala Sekolah. Hasil penelitian menunjukkan bahwa dengan adanya supervisi kepala sekolah mengalami peningkatan sebesar 30\%, hasil belajar siswa rata-rata mencapai sebesar 62.66 menjadi 85.33 dengan meningkatkan prestasi belajar siswa. Dengan demikian dapat disimpulkan bahwa dengan adanya bimbingan dan Supervisi Kepala Sekolah dapat meningkatkan prestasi belajar siswa. Oleh karena itu diharapkan agar selalu meningkatkan kemampuan kinerjanya dalam pembelajaran sehingga mutu pendidikan di Sekolah semakin meningkat.
\end{abstract}

Kata Kunci: prestasi belajar matematika, kemampuan kinerja guru dan bimbingan dan pengawasan

\begin{tabular}{|c|c|c|}
\hline Submitted & Accepted & Published \\
\hline 11 April 2020 & 14 Juli 2020 & 26 Juli 2020 \\
\hline
\end{tabular}

\begin{tabular}{|l|c|c|}
\hline Citation & $:$ & $\begin{array}{r}\text { Rohaimi. (2020). The Improvement Mathematics Learning Achievement by Improving Teacher Performance Capabilities } \\
\text { through Guidance and Supervision by Principals. Jurnal PAJAR (Pendidikan dan Pengajaran), 4(4), 855-865. } \\
\text { DOI : http://dx.doi.org/10.33578/pjr.v4i2.8017. }\end{array}$ \\
\hline
\end{tabular}




\section{PENDAHULUAN}

Pendidikan adalah sesuatu yang essensial/ penting di dalam kehidupan. Baik itu kehidupan berbangsa dan bernegara, bermasyarakat ataupun dalam kehidupan berkeluarga. Banyak faktor yang mempengaruhi keberhasilan dalam dunia pendidikan. Faktor tersebut antara lain adalah kurikulum, sarana prasarana, input siswa dan terutama factor tertentu dari keberhasilan tersebut adalah guru sebagai tenaga pendidik.

Dalam menuju era globalisi yang penuh dengan tantangan, mutu sumber daya manusia sangat perlu untuk ditingkatkan dan pendidikan merupakan salah satu sektor yang perlu untuk diperhatikan dengan seksama. Pendidikan sangat fundamental bagi setiap warga masyarakat karena dengan pendidikan akan menjamin perkembangan dan kelangsungan kehidupan bangsa. Maju atau mundurnya suatu negara sebagian besar ditentukan oleh pendidikan.

Guru sebagai pelaksana pendidikan yang bertemu dan berinteraksi langsung dengan siswa, memiliki peran yang sangat besar dalam peningkatan mutu pendidikan di Indonesia. Guru menjadi penentu naik atau turunnya mutu pendidikan. Guru merupakan ujung tombak yang paling berpengaruh terhadap terbentuknya proses belajar yang optimal dan tentunya hasil belajar yang berkualitas. Oleh karena itu, usaha untuk memperbaiki atau meningkatkan kualitas pendidikan tidak akan terlaksana dengan optimal tanpa didukung oleh guru yang profesional dan berkualitas. Guru sebagai tenaga pendidik memiliki peran yang sangat penting dan strategis dalam mencapai tujuan pembangunan dalam bidang pendidikan. Sedangkan menurut Davies dan Ellison dalam Baedhowi (Baedowi, 2006, p. 276) guru merupakan the keyperson in the classroom. Maksudnya adalah guru adalah kunci dari baik atau buruknya hasil belajar siswa di kelas. Mengingat bahwa peran guru tidak akan dapat digantikan oleh apapun. Guru yang dimaksud adalah guru yang memiliki pengetahuan dan wawasan yang luas serta guru yang memiliki kompetensi yang sesuai.

Selanjutnya, Anwar Prabu Mangkunegara (2001, p. 67)menjelaskan bahwa "kinerja adalah hasil kerja secara kualitas dan kuantitas yang dicapai oleh seorang pegawai dalam melaksanakan tugasnya sesuai dengan tanggung jawab yang diberikan kepadanya". Menurut Mulyasa (2013) "Kinerja adalah unjuk kerja seseorang yang ditunjukkan dalam penampilan, perbuatan, dan prestasi kerjanya sebagai akumulasi dari hasil pengetahuan, keterampilan, nilai, dan sikap yang telah dimilikinya." Hadari Nawawi (2006, p. 66) juga menyatakan bahwa "kinerja dapat diartikan sebagai apa yang dikerjakan atau tidak dikerjakan oleh seorang karyawan dalam melaksanakan tugastugas pokoknya". Sedangkan Wibowo $(2011$, p. 7) memberikan pengertian bahwa "kinerja adalah tentang melakukan pekerjaan dan hasil yang dicapai dari pekerjaan tersebut". Dari berbagai pendapat diatas dapat ditarik kesimpulan bahwa kinerja merupakan unjuk kerja seseorang yang ditunjukkan dalam melakukan kerjanya sebagai hasil pengetahuan, keterampilan, nilai, dan sikap yang telah dimilikinya

Guru diwajibkan untuk mempunyai kinerja yang baik agar pelaksanaan pendidikan dapat terlaksana dengan baik. Menurut Hamzah B. Uno dan Nina Lamatengga ( 2012, p. 63) "kinerja guru sekolah dasar dapat terlihat pada kegiatan merencanakan, melaksanakan, dan menilai proses belajar mengajar yang intensitasnya dilandasi etos kerja dan disiplin profesional guru". Hal yang sama diungkapkan Soedijarto (2008, p. 178) bahwa "kinerja guru meliputi merencanakan, mengelola pelaksanaan, menilai proses dan hasil, mendiagnosis kesulitan belajar, dan merevisi program pembelajaran". Dari pendapat tersebut dapat digaris bawahi bahwa kinerja guru sangat banyak sekali mulai dari merencanakan pembelajaran atau RPP, melaksanakan pembelajaran di depan siswa, serta melakukan penilaian dalam pembelajaran yang telah dilalui. Guru dikatakan memiliki kinerja yang baik apabila telah melaksanakan kegiatan-kegiatan tersebut dengan baik dan sesuai aturan yang telah ditentukan. Keseriusan kerja dapat terlihat dalam usaha guru dalam merancang rencana pelaksanaan pembelajaran yang sesuai dengan kebutuhan peserta didik, melaksanakan pembelajaran dengan yang telah disusun, mengevaluasi hasil belajar dengan objektif. 
Berdasarkan Undang-Undang Republik Indonesia No 20 tahun 2003 Bab XI Pasal 39 ayat 2 tentang Sistem Pendidikan Nasional, dijelaskan bahwa pendidik merupakan tenaga professional yang bertugas merencanakan dan melaksanakan proses pembelajaran, melakukan bimbingan dan pelatihan, serta melakukan penelitian dan pengabdian kepada masyarakat, terutama bagi pendidik di perguruan tinggi.

Matematika merupakan suatu bahan kajian yang memiliki obyek abstrak dan dibangun melalui proses penalaran deduktif, kebenaran suatu konsep diperoleh sebagai akibat logis dari kebenaran sebelumnya sudah diterima sehingga keterkaitan antar konsep dalam Matematika bersifat sangat kuat dan jelas ( Standar Kompetensi, 2004:3 ). Dalam proses belajar mengajar Matematika di Sekolah Dasar kita harus mengacu pada tujuan pengajaran dalam standar kompetensi yang telah ditentukan. Agar tujuan pengajaran tersebut tercapai, guru harus dapat memilih strategi pembelajaran, metode pembelajaran, dan media pembelajaran yang sesuai dengan karakteristik siswa dan karakteristik mata pelajaran. Menurut Caroll dalam Sudjana terdapat lima faktor yang menentukan keberhasilan belajar yaitu : (1) Bahan belajar, (2) Waktu belajar, (3) Waktu yang diperlukan siswa untuk menyelesaikan atau menguasai bahan pelajaran, (4) Kwalitas pelajaran, (5) Kemampuan individu.(Sudjana, 2005, p. 40) Berdasarkan pendapat Caroll di atas dapat diidentifikasi bahwa kemampuan individu adalah faktor dalam. Sedangkan bahan pelajaran, waktu belajar, waktu yang diperlukan menyelesaikan atau menguasai bahan pelajaran dan kualitas pengajaran adalah faktor luar.

Merosotnya prestasi belajar Matematika di sekolah dewasa ini, mendapat sorotan tajam dari kalangan pendidikan dan masyarakat pada umumnya. Merosotnya prestasi belajar Matematika juga menandakan rendahnya mutu pendidikan di sekolah-sekolah. Kenyataan serupa juga terjadi di SD Negeri 137 Pekanbaru. Berdasarkan pengamatan, nilai tes sumatif (akhir semester), nilai tes Formatif (ulangan harian) rata-rata hasil belajar siswa menurun, begitu juga untuk mata pelajaran Matematika. Banyak kemungkinan faktor yang menyebabkan rendahnya prestasi belajar Matematika, apakah bakat dan minatnya rendah, kurangnya motivasi dan semangat, pengaruh keluarga, media masa, dan pengaruh lingkungan.

Karena hal tersebut, maka peneliti berusaha untuk memperbaiki proses pembelajaran di kelas dengan mengadakan bimbingan dan supervisi kelas. Peneliti juga mengajak rekanrekan guru di SD Negeri 137 Pekanbaru untuk memanfaatkan media dan metode yang lebih menarik dan dapat memotivasi minat anak dalam belajar, sehingga dapat meningkatkan mutu pembelajaran di kelas. Dengan meningkatnya mutu pembelajaran tersebut, diharapkan tujuan pembelajaran akan tercapai seoptimal mungkin.

Kegiatan atau usaha-usaha yang dapat dilakukan oleh kepala sekolah sesuai dengan fungsinya sebagai supervisor antara lain: 1) Membangkitkan dan merangsang guru-guru dan pegawai sekolah di dalam menjalankan tugasnya masing-masing dengan sebaik-baiknya. 2) Berusaha mengadakan dan melengkapi alat-alat perlengkapan sekolah termasuk media instruksional yang diperlukan bagi kelancaran dan keberhasilan proses belajar-mengajar. 3) Bersama guru-guru berusaha mengembangkan, mencari, dan menggunakan metode-metode mengajar yang lebih sesuai dengan tuntutan kurikulum yang sedang berlaku. 4) Membina kerja sama yang baik dan harmonis di antara guru-guru dan pegawai sekolah lainnya. 5) Berusaha mempertinggi mutu dan pengetahuan guru-guru dan pegawai sekolah, antara lain dengan mengadakan diskusi-diskusi kelompok, menyediakan perpustakaan sekolah, dan atau mengirim mereka untuk mengikuti penataranpenataran, seminar, sesuai dengan bidangnya masing-masing. 6) Membina hubungan kerja sama antara sekolah dengan BP3 atau komite sekolah dalam rangka peningkatan mutu pendidikan para siswa.

Bertitik tolak dari latar belakang masalah yang penulis uraikan di atas, maka penulis terdorong untuk melakukan penelitian mengenai Peningkatan Prestasi Belajar Matematika dengan Meningkatkan Kemampuan Kinerja Guru melalui Bimbingan dan Supervisi Kepala Sekolah. 


\section{KAJIAN TEORETIS}

Prestasi Belajar

Prestasi belajar merupakan gabungan dari dua kata, yaitu prestasi dan belajar, yang mana pada setiap kata tersebut memiliki makna tersendiri. Dalam kamus besar bahasa Indonesia, prestasi adalah hasil yang telah dicapai (dari yang telah dilakukan, dikerjakan, dan sebagainya). Prestasi dapat diartikan sebagai hasil yang diperoleh karena adanya aktivitas belajar yang telah dilakukan.(Fathurrahman \& Sulistyorini, 2102, p. 118) Sardiman juga mengemukakan pendapat serupa, Menurutnya Prestasi adalah kemampuan nyata yang merupakan hasil interaksi antara berbagai faktor yang mempengaruhi baik dari dalam maupun dari luar diri individu dalam belajar.(Sardiman A.M, 2011, p. 46) Selanjutnya Marsun dan Martaniah dalam Hidayat (Hidayat et al., 2013, p. 83) berpendapat bahwa prestasi belajar merupakan hasil kegiatan belajar, yaitu sejauh mana peserta didik menguasai bahan pelajaran yang diajarkan, yang diikuti oleh munculnya perasaan puas bahwa ia telah melakukan sesuatu dengan baik. Dari ketiga pendapat di atas dapat digaris bawahi bahwa prestasi adalah Hasil dari perlakuan yang diberikan kepada siswa.

Kata kedua adalah belajar. Menurut Slameto, Belajar merupakan suatu proses usaha yang dilakukan seseorang untuk memperoleh suatu perubahan tingkah laku yang baru secara keseluruhan, sebagai hasil pengalaman sendiri dalam interaksi dengan lingkungannya.(Slameto, 2010 , p. 2) senada dengan pendapat di atas, Usman mengemukakan bahwa belajar adalah Perubahan tingkah laku pada diri individu berkat adanya interaksi antara satu individu dengan individu lainnya dan antara individu dengan lingkungan". (Uzer Usman, 2000, p. 5) Menurut Trianto (2010: 16), Trianto juga mengemukakan bahwa belajar adalah proses belajar terjadi melalui banyak cara baik di sengaja maupun tidak di sengaja dan berlangsung sepangjang waktu dan menuju pada suatu perubahan pada diri pembelajar.(Trianto, 2010 , p. 16). Dari tiga pendapat di atas dapat disimpulkan bahwa belajar adalah perubahan tingkah laku yang terjadi pada diri pembelajar melalui proses yang terjadi baik antara pembelajar dan pembelajar yang lain maupun antara pembelajar dan lingkungan.

Dalam kamus besar Bahasa Indonesia disebutkan bahwa prestasi belajar adalah penguasaan pengetahuan atau keterampilan yang dikembangkan oleh mata pelajaran yang lazimnya ditunjukkan dengan nilai tes atau angka yang diberikan oleh guru.(Poerwardaminta, 2007, p. 787) sedangkan menurut Syaiful Bahri Djamarah prestasi belajar adalah apa yang telah dicapai, hasil pekerjaan yang menyenangkan hati yang dipeoleh dengan jalan keuletan bekerja atau dengan kata lain Prestasi belajar adalah hasil dari suatu kegiatan yang telah dikerjakan, diciptakan, baik secara individu maupun kelompok.(Syaiful Bahri Djamarah, 2006, p. 45) WS Winkel juga mengemukan bahwa prestasi belajar adalah keberhasilan usaha yang dicapai seseorang setelah memperoleh pengalaman belajar atau mempelajari sesuatu.(Winkel, 1987) berdasarkan penjelasan para ahli di atas dapat disimpulkan bahwa prestasi belajar adalah keberhasilan usaha yang dicapai oleh pembelajar baik dalam cakupan pengetahuan maupun keterampilan.

Faktor-faktor yang mempengaruhi prestasi belajar menurut Baharuddin dan Elsa Nur dibedakan menjadi dua kategori yaitu: 1) Faktor Internal merupakan faktor-faktor yang berasal dari dalam diri individu dan dapat mempengaruhi Prestasi Belajar individu. Faktor-faktor internal ini terdiri dari faktor fisiologis dan psikologis. 2) Faktor Eksternal, dibedakan menjadi dua yaitu lingkungan sosial seperti lingkungan sosial sekolah yang di dalamnya termasuk guru, administrasi dan Teman Sebaya, lingkungan sosial masyarakat, dan lingkungan sosial keluarga seperti ketegangan keluarga, sifat-sifat orang tua, demografi keluarga, status sosial ekonomi. Sedangkan lingkungan nonsosial terdiri dari lingkungan alamiah, faktor instrumental, faktor materi pelajaran. (Baharudin \& Wahyuni, 2010, p. 19)

\section{Supervisi Kepala Sekolah}

Munurut Suharsimi Istilah supervisi berasal dari bahasa Inggris yang terdiri dari dua akar kata, yaitu: super yang artinya "di atas" dan vision mempunyai arti "melihat" maka secara 
keseluruhan supervisi diartikan sebagai "melihat dari atas". Dengan pengertian itulah maka supervisi diartikan sebagai kegiatan yang dilakukan oleh pengawas dan kepala sekolah, karena sebagai pejabat yang berkedudukan di atas atau yang lebih tinggi dari guru.(Suharsimi Arikunto, 2004, p. 4) sejalan dengan itu, Wiles dalam Burhanuddin mengemukakan bahwa supervisi pendidikan adalah segenap bantuan yang diberikan oleh seseorang dalam mengembangkan situasi belajar ke arah yang lebih baik. (Burhanuddin, 2007, p. 1) sedangkan Menurut Burton dan Brueckner (1955) dalam Syaiful supervisi adalah suatu teknik pelayanan yang tujuan utamanya mempelajari dan memperbaiki secara bersama-sama faktor-faktor yang mempengaruhi pertumbuhan dan perkembangan anak. (Syaiful Sagala, 2009, p. 194) berdasarkan beberapa pengertian di atas dapat digarisbawahi bahwa supervisi adalah suatu kegiatan yang dilakukan oleh atasan (dalam hal ini adalah kepala sekolah) dan guru guna untuk mengevaluasi dan mengembangkan situasi belajar ke arah yang lebih baik.

Menurut Mulyasa salah satu supervisi akademik yang popular adalah supervisi klinis, yang memiliki karakteristik sebagai berikut: 1) Supervisi diberikan berupa bantuan (bukan perintah),sehingga inisiatif tetap berada di tangan tenaga kependidikan. 2) Supervisi dilakukan dalam suasana terbuka secara tatap muka, dan supervisor lebih banyak mendengarkan serta menjawab pertanyaan guru daripada memberi saran dan pengarahan. 3) Supervisi dilakukan secara berkelanjutan untuk meningkatkan suatu keadaan dan memecahkan suatu masalah.Supervisi Klinis sedikitnya memiliki tiga tahap, yaitu pertemuan awal, pengamatan dan umpan balik. 4) Aspek yang disupervisi berdasarkan usul guru, yang dikaji bersama kepala sekolah sebagai supervisor untuk dijadikan kesepakatan. 5) Instrumen dan metode observasi dikembangkan bersama oleh guru dan kepala sekolah. 6) Mendiskusikan dan menafsirkan hasil pengamatan dengan mendahulukan interpretasi guru. 7) Mendiskusikan dan menafsirkan hasil pengamatan dengan mendahulukan interpretasi guru. 8) adanya penguatan dan umpan balik dari kepala sekolah sebagai supervisor terhadap perubahan perilaku guru yang positif sebagai hasil pembinaan. (Mulyasa, 2004, p. 112)

\section{Fungsi Kepala Sekolah Sebagai Supervisor}

Kegiatan atau usaha-usaha yang dapat dilakukan oleh kepala sekolah sesuai dengan fungsinya sebagai supervisor antara lain: 1) Membangkitkan dan merangsang guru-guru dan pegawai sekolah di dalam menjalankan tugasnya masing-masing dengan sebaik-baiknya. 2) Berusaha mengadakan dan melengkapi alat-alat perlengkapan sekolah termasuk media instruksional yang diperlukan bagi kelancaran dan keberhasilan proses belajar-mengajar. 3) Bersama guru-guru berusaha mengembangkan, mencari, dan menggunakan metode-metode mengajar yang lebih sesuai dengan tuntutan kurikulum yang sedang berlaku. 4) Membina kerja sama yang baik dan harmonis di antara guru-guru dan pegawai sekolah lainnya. 5) Berusaha mempertinggi mutu dan pengetahuan guru-guru dan pegawai sekolah, antara lain dengan mengadakan diskusi-diskusi kelompok, menyediakan perpustakaan sekolah, dan atau mengirim mereka untuk mengikuti penataranpenataran, seminar, sesuai dengan bidangnya masing-masing. 6) Membina hubungan kerja sama antara sekolah dengan BP3 atau komite sekolah dalam rangka peningkatan mutu pendidikan para siswa.

\section{Teknik-Teknik Supervisi}

Menurut Purwanto secara garis besar cara atau tehnik supervisi dapat digolongkan menjadi dua, yaitu tehnik perseorangan dan teknik kelompok. Teknik perseorangan ialah supervisi yang dilakukan secara perseorangan. Beberapa kegiatan yang dapat dilakukan antara lain : 1) Mengadakan kunjungan kelas (classroom visition). 2) Mengadakan kunjungan observasi (observation visits). 3) Membimbing guru-guru tentang caracara mempelajari pribadi siswa dan atau mengatasi problema yang dialami siswa. 4) Membimbing guru-guru dalam hal-hal yang berhubungan dengan pelaksanaan kurikulum sekolah. Supervisi ini dilakukan secara kelompok. Beberapa kegiatan yang dapat dilakukan antara lain : 1) Mengadakan pertemuan atau rapat (meetings). 2) Mengadakan 
diskusi kelompok (group discussions). 3) training). (Purwanto, 2004, p. 120). Mengadakan penataran-penataran (inservice-

\section{METODE PENELITIAN}

Penelitian ini merupakan penelitian tindakan sekolah. Adapun penelitian ini menggunakan alur yang dikemukakan oleh Hopkins dan Mc Tagaart dalam wayan (2010) terdiri dari empat tahapan yaitu : perencanaan, pelaksanaan tindakan, observasi dan refleksi. Penelitian ini dilakukan di SD Negeri 137 Pekanbaru Jl Riau, Kel. Tampan, Kec. Payung
Sekaki, Kota Pekanbaru. Subjek dan objek penelitian adalah guru dan siswa SD Negeri 137 Pekanbaru. Teknik pengumpulan data penelitian ini adalah dengan observasi dan tes. Kriteria untuk mengukur keberhasilan pembelajaran Matematika apabila $75 \%$ dari jumlah siswa tuntas dalam belajar. (Mulyasa, 2013, p. 172).

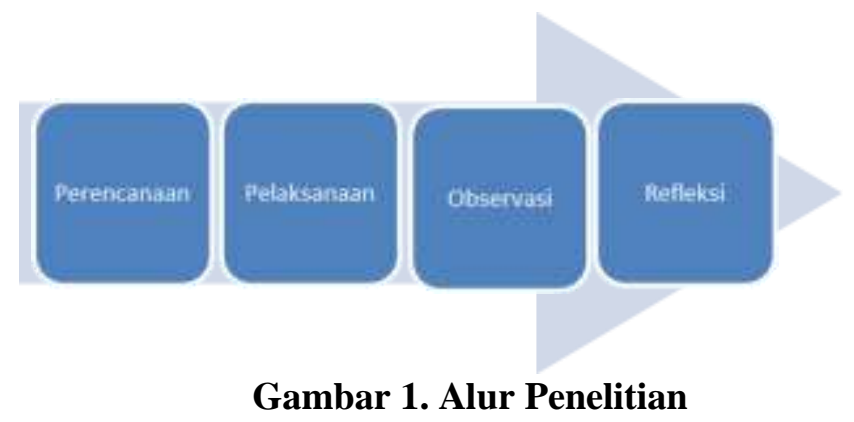

\section{HASIL DAN PEMBAHASAN}

Data penelitian yang diperoleh adalah data proses pembelajaran yang dilakukan oleh guru SD Negeri 137 Pekanbaru dalam upaya meningkatkan prestasi belajar matematika siswayang disajikan dalam dua siklus. Berikut adalah perbandingan peningkatan prestasi belajar matematika dalam

proses pembelajaran dari siklus I ke siklus II.

\section{Siklus I}

Pelaksanaan penelitian dalam siklus I oleh peneliti dapat dilihat pada tabel 1 di bawah.

\section{Tabel 1. Tahapan Penelitian Tindakan Sekolah Siklus I}

\begin{tabular}{ll}
\hline Tahapan & Perlakuan \\
\hline Perencanaan & Mempersiapkan lembar observasi \\
& Mempersiapkan lembar kerja Mempersiapkan materi \\
& Mempersiapkan lembar evaluasi untuk akhir siklus pertama. \\
Pelaksanaan & Kepala sekolah mengadakan observasi terhadap Pelaksanaan \\
& pembelajaran oleh guru \\
Observasi & Mengamati aktivitas guru dalam pembelajaran \\
& Mengamati aktivitas siswa dalam pembelajaran yang dilakukan oleh \\
Refleksi & Menger \\
& Membelaluasi hasil observasi guru dalam Pengelolaan proses \\
& Mengevaluasi hasil observasi kemampuan Kinerja guru selama proses \\
& pembelajaran \\
& Menganalisa hasil observasi aktifitas siswa dan Guru. \\
& Memperbaiki siklus I untuk pelaksanaan siklus selanjutnya. \\
\hline
\end{tabular}


Hasil pengamatan observer terhadap Kinerja guru dapat dilihat pada tabel. 2 berikut.

Tabel 2. Rekapitulasi Kinerja Guru

\begin{tabular}{cc}
\hline Kelas & Kinerja guru (\%) \\
\hline Guru IV A & 70 \\
Guru IV B & 80 \\
Guru IV C & 80 \\
Guru IV D & 90 \\
Guru V A & 65 \\
Guru V B & 85 \\
Guru V C & 80 \\
Guru V D & 80 \\
Guru VI A & 80 \\
Guru VI B & 80 \\
Guru VI C & 75 \\
Guru VI D & 85 \\
\hline Rata-rata & 79.16 \\
\hline
\end{tabular}

Berdasarkan tabel 2 di atas dapat kita lihat kinerja guru memperoleh rata-rata $79.16 \%$ dengan kategori cukup. 8 orang guru telah memperlihatkan kinerja dengan kategori Baik dan 4 orang guru masih memperoleh nilai kinerja dengan kategori cukup.

Berdasarkan analisis dan masukan dari kepala sekolah sebagai supervisor, diketahui bahwa terdapat beberapa tindakan yang kurang optimal dilaksanakan dan juga ada yang terlewatkan dalam proses pembelajaran yang dilakukan oleh guru. Untuk itu sebelum melanjutkan ke siklus II maka peneliti merefleksikan hasil pengamatan dan memberikan bimbingan kepada guru bersangkutan agar dapat diperbaiki pada siklus berikutnya.

Setelah melaksanakan pembelajaran siklus I guru memberikan evalusI berupa tes. Berikut rekapitulasi nilai prestasi belajar siswa pada pembelajaran siklus I dapat dilihat pada tabel 3 dibawah.

\begin{tabular}{cc}
\multicolumn{2}{c}{ Tabel 3. Rekapitulasi Prestasi Belajar Matematika } \\
\hline Kelas & Rata-rata Prestasi Belajar Matematika \\
\hline IV A & 50 \\
IV B & 56 \\
IV C & 42 \\
IV D & 45 \\
V A & 55 \\
V B & 60 \\
V C & 55 \\
V D & 63 \\
VI A & 80 \\
VI B & 84 \\
VI C & 82 \\
VI D & 80 \\
\hline Rata-rata & 62.66 \\
\hline
\end{tabular}

Berdasarkan tabel 3 di atas terlihat bahwa rata-rata prestasi belajar matematika siswa adalah 62.66 dengan kategori kurang baik. Rata-rata tertinggi diperoleh oleh kels VI B dengan nilai 84, sedangkan Rata-rata terendah adalah 42 yang diperoleh oleh kelas IV C. Setalah melakukan 
refleksi dan evaluasi maka akan dilanjutkan penelitian pada siklus II karena ketuntasan siswa belum mencapai indikator keberhasilan pada penelitian ini yaitu $75 \%$.

\section{Siklus II}

Pelaksanaan penelitian dalam siklus II oleh peneliti dapat dilihat pada tabel.4 dibawah.

Tabel 4. Tahapan Penelitian Tindakan Sekolah Siklus II

\begin{tabular}{|c|c|}
\hline Tahapan & Perlakuan \\
\hline \multirow[t]{4}{*}{ Perencanaan } & Sosialisasi pelaksanaan siklus 2 \\
\hline & $\begin{array}{l}\text { Menyusun jadwal pelaksanaan pembelajaran Matematika dan supervisi } \\
\text { kepala sekolah }\end{array}$ \\
\hline & $\begin{array}{l}\text { Memadukan hasil refleksi siklus } 1 \text { agar pelaksanaan pada siklus } 2 \text { lebih } \\
\text { efektif }\end{array}$ \\
\hline & $\begin{array}{l}\text { Membuat lembar observasi atau instrumen penelitian untuk memantau } \\
\text { proses pembelajaran }\end{array}$ \\
\hline Pelaksanaan & $\begin{array}{l}\text { Kepala sekolah mengadakan observasi terhadap Pelaksanaan } \\
\text { pembelajaran oleh guru }\end{array}$ \\
\hline \multirow[t]{2}{*}{ Observasi } & Mengamati aktivitas guru dalam pembelajaran \\
\hline & $\begin{array}{l}\text { Mengamati aktivitas siswa dalam pembelajaran yang dilakukan oleh } \\
\text { observer }\end{array}$ \\
\hline \multirow[t]{3}{*}{ Refleksi } & $\begin{array}{l}\text { Mengevaluasi hasil observasi guru dalam Pengelolaan proses } \\
\text { pembelajaran. }\end{array}$ \\
\hline & $\begin{array}{l}\text { Mengevaluasi hasil observasi kemampuan Kinerja guru selama proses } \\
\text { pembelajaran }\end{array}$ \\
\hline & Menganalisa hasil observasi aktifitas siswa dan Guru. \\
\hline
\end{tabular}

Hasil pengamatan observer terhadap Kinerja guru dapat dilihat pada tabel.5 berikut.

Tabel 5. Rekapitulasi Kinerja Guru

\begin{tabular}{lc}
\hline Kelas & Kinerja guru (\%) \\
\hline Guru IV A & 85 \\
Guru IV B & 90 \\
Guru IV C & 85 \\
Guru IV D & 90 \\
Guru V A & 75 \\
Guru V B & 85 \\
Guru V C & 85 \\
Guru V D & 90 \\
Guru VI A & 85 \\
Guru VI B & 90 \\
Guru VI C & 80 \\
Guru VI D & 95 \\
\hline \multicolumn{1}{c}{ Rata-rata } & 86.25 \\
\hline
\end{tabular}

Berdasarkan tabel 5 di atas dapat kita lihat kinerja guru memperoleh rata-rata $86.25 \%$ dengan kategori baik. 11 orang guru telah memperlihatkan kinerja dengan kategori Baik dan 1 orang guru masih memperoleh nilai kinerja dengan kategori cukup.
Setelah melaksanakan pembelajaran siklus II, guru memberikan evalusi berupa tes. Berikut rekapitulasi nilai prestasi belajar siswa pada pembelajaran siklus I dapat dilihat pada tabel 6 di bawah. 
Tabel 6. Rekapitulasi Prestasi Belajar Matematika

\begin{tabular}{cc}
\hline Kelas & Rata-rata Prestasi Belajar Matematika \\
\hline IV A & 80 \\
IV B & 82 \\
IV C & 75 \\
IV D & 78 \\
V A & 85 \\
V B & 80 \\
V C & 89 \\
V D & 90 \\
VI A & 95 \\
VI B & 90 \\
VI C & 90 \\
VI D & 90 \\
\hline Rata-rata & 85.33 \\
\hline
\end{tabular}

Berdasarkan tabel.4 di atas terlihat bahwa rata-rata prestasi belajar matematika siswa adalah 85.33 dengan kategori amat baik. Rata-rata tertinggi diperoleh oleh kelasVI A yaitu 95 dan rata-rata terendah adalah 75 yang diperoleh oleh kelas IV C. Setalah melakukan refleksi dan evaluasi maka tidak pelu dilanjutkan penelitian pada siklus III karena ketuntasan siswa telah mencapai indikator keberhasilan pada penelitian ini yaitu $75 \%$.

Berdasarkan indikator keberhasilan yang ditetapkan, maka kegiatan supervisi akademik ini dinyatakan berhasil. Peningkatan prestasi belajar matematika dalam pembelajaran dari siklus I ke siklus II dapat dilihat pada gambar 2 berikut:

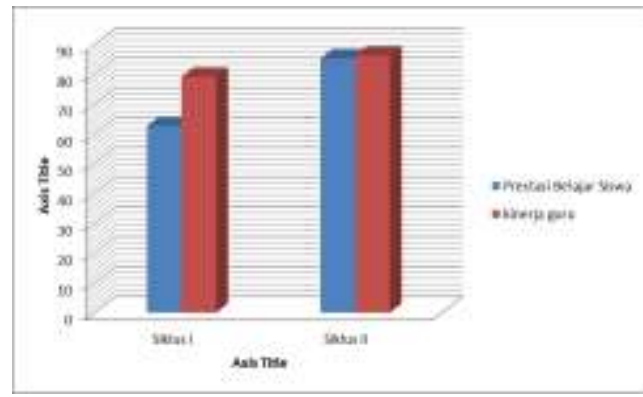

\section{Gambar 2. Rekapitulasi Prestasi Belajar Matematika}

Berdasarkan gambar.2 di atas dapat kita lihat bahwa terdapat peningkatan prestasi belajar matematika siswa. Pada siklus I prestasi belajar matematika siswa memperoleh rata-rata sebesar 62.66 dengan kategori kurang dan rata-rata kinerja

\section{Pembahasan}

Hasil penelitian ini diperkuat teori-teori dan penelitan sebelumnya. Seperti penelitian yang dilakukan oleh Hasnah dengan menunjukkan bahwa Hasil penelitian tindakan ini menunjukkan bahwa pembinaan melalui supervisi akademis guru adalah 79,16\% dengan kategori cukup, sedangkan pada siklus II mengalami peningkatan prestasi belajar matematika menjadi 85.33 dengan kategori amat baik dan rata-rata kinerja guru juga meningkat menjadi $86.25 \%$ dengan kategori baik.

kepala sekolah dapat meningkatkan kinerja guru dalam pengembangan evaluasi hasil belajar dengan ketuntasan mencapai $100 \%$ (Hasnah, 2019). Hal senada juga ditemui oleh Kustiyah dengan menunjukkan bahwa hasil penelitian 
tindakan di atas dapat disimpulkan bahwa supervisi akademik kepala sekolah dengan pendekatan individual memberikan pengaruh terhadap peningkatan prestasi kinerja guru SD Candi 01 Kecamatan Candisari Kota Semarang baik komponen perencanaan pembelajaran, pelaksanaan pembelajaran dan evaluasi. (Kustiyah, 2017). Akhmad Zaenal Abidin juga menemukan hal yg serupa bahwa Hasil penelitian tindakan ini menunjukkan bahwa pembinaan melalui supervisi akademik dapat meningkatkan

\section{SIMPULAN DAN REKOMENDASI}

Berdasarkan uraian yang telah dipaparkan di atas, maka dapat disimpulkan bahwa terdapat peningkatan prestasi belajar siswa dengan meningkatkan kinerja guru melalui bimbingan dan supervisi kepala sekolah. Hal ini dibuktikan dengan terjadinya peningkatan kinerja guru dari $79.16 \%$ menjadi $86.25 \%$ dan juga berimbas pada peningkatan pada prestasi belajar matematika dari rata-rata 62.66 menjadi 85.33 . Artinya bimbingan dan supervisi kepala sekolah dapat meningkatkan

\section{DAFTAR PUSTAKA}

Abidin, A. Z. (2019). Peningkatan Kinerja Guru dengan Pengefektifkan Musyawarah Guru Mata Pelajaran (MGMP) Matematika melalui Supervisi Akademik Kepala Sekolah di SMP Negeri 3 Sikur. Jurnal EDISI, 1 (2).

Arikunto, S. (2004). Dasar-Dasar Supervisi. Jakarta: Rineka Cipta.

AS Wayan. (2010). Akuntabilitas Kinerja Kepala Sekolah Dan Penelitian Tindakan Sekolah Untuk Kepala Sekolah Dalam Rangka Peningkatan Mutu Pembelajaran Serta Bahan Belajar Mandiri Dimensi Kompetensi Kepala Sekolah. Az-Zahra Book.

Baedowi. (2006). Tantangan Peningkatan Profesional Tenaga Pendidik pada Era Undang-Undang Guru dan Dosen. Jakarta: Badan Penelitian dan Pengembangan Departemen Pendidikan Nasional. kinerja guru di SMP Negeri 3 Sikur dengan ketuntasan sesuai yang diharapkan.(Abidin, 2019).

Hasil penelitian di atas sangat sesuai dengan pendapat Wiles (1975) bahwa supervisi sebagai bantuan dalam pengembangan situasi belajar yang lebih baik.. Lebih lengkap, Schubert (1986) menjelaskan bahwa supervisi merupakan sebuah proses yang memberikan inspirasi, makna membantu, umpan balik serta motivasi untuk mencapai tujuan pendidikan yang telah ditetapkan.

kinerja guru, dengan meningkatnya kinerja guru maka prestasi belajar matematika siswa juga terjadi peningkatan.

Mengacu pada kesimpulan di atas, peneliti memberikan saran agar guru lebih meningkatkan lagi kinerjanya, karena guru merupakan ujung tombak pendidikan dan kepada peneliti selanjutnya agar lebih menekankan atau lebih dalam membahas tentang kinerja guru agar dapat lebih meningkatkan prestasi belajar siswa.

Baharudin, \& Wahyuni, E. N. (2010). Teori Belajar dan Pembelajaran. Yogyakarta: Ar-Ruzz Media.

Burhanuddin. (2007). Supervisi Pendidikan dan Pengajaran. Malang: Rosindo.

Fathurrahman, M., \& Sulistyorini. (2102). Belajar dan Pembelajaran. Teras.

Hasnah. (2019). Upaya Peningkatan Kinerja Guru dalam Pengembangan Evaluasi Hasil Belajar Melalui Supervisi Akademis Kepala Sekolah. Jurnal Pendidikan Tambusai, 3(3), 1023-1031

Hidayat, S., \& Asroi. (2013). Manajemen Pendidikan Substansi dan Implementasi dalam Praktik Pendidikan di Indonesia. Tangerang: Pustaka Mandiri.

Kustiyah. (2017). Meningkatkan Kinerja Guru melalui Supervisi Akademik Kepala Sekolah dengan Pendekatan Individual di SD Candi 01 Kecamatan Candisari Kota 
Semarang Semester II Tahun Pelajaran 2013/2014. Malih Peddas, 7(1), 11-20.

Mulyasa. (2013). Pengembangan dan Implementasi Kurikulum 2013. Bandung: Remaja Rosdakarya.

Mulyasa, E. (2004). Manajemen Berbasis Sekolah. Bandung: Remaja Rosdakarya.

Mangkunegara, A. A. A. P. (2000). Manajemen Sumber Daya Manusia Perusahaan. Bandung: Remaja Rosdakarya.

Nawawi, H. (2006). Evaluasi dan Manajemen Kinerja Di Lingkungan Perusahaan dan Industri. Yogyakarta: Gadjah Mada University press.

Poerwardaminta. (2007). Kamus Besar Bahasa Indonesia. Jakarta: PN Balai Pustaka.

Purwanto, N. (2004). Administrasi dan Supervisi Pendidikan. $\quad$ Bandung: Remaja Rosdakarya.

Sagala, S. (2009). Kemampuan Profesional Guru dan Tenaga Kependidikan. Bandung: Alfabeta.

Sardiman A.M. (2011). Interaksi dan Motivasi Belajar Mengajar. Jakarta: Rajawali Pers.

Slameto. (2010). Belajar dan Faktor-faktor yang Mempengaruhinya. Rineka Cipta.

Soedijarto. (2008). Landasan dan Arah Pendidikan Nasional Kita. Gramedia pustaka.

Sudjana, N. (2005). Penelitian Hasil Belajar Mengajar. Bandung: Remaja Rosdakarya.

Syaiful, B. D. (2006). Guru dan Anak Didik dalam Interaksi Edukatif. Jakarta: Rineka Cipta.

Trianto. (2010). Model Pembelajaran InovatifProgresif Konsep, Landasan, dan Implementasi Pada Kurikulum Tingkat Satuan Pendidikan (KTSP). Jakarta: Kencana.

Uno, H. B., \& Lamatenggo., N. (2012). Teori Kinerja dan Pengukurannya. Jakarta: Bumi Aksara.

Uzer, U. M. (2000). Menjadi Guru Profesional. Bandung: Remaja Rosdakarya.

WH Schubert. (1986). Curriculum: Perspective, Paradigm and Possibility. New York: Macmillan Pub.

Wibowo. (2011). Manajemen Kinerja. Depok: Raja Grafindo Persada.
Wiles, K., \& Jhon Lovell. (1975). supervision for better school (4th ed.). New Jersey: Prentice - Hall, Inc.

Winkel, W. (1987). Bimbingan dan Konseling di Institusi Pendidikan. Jakarta: Gramedia. 